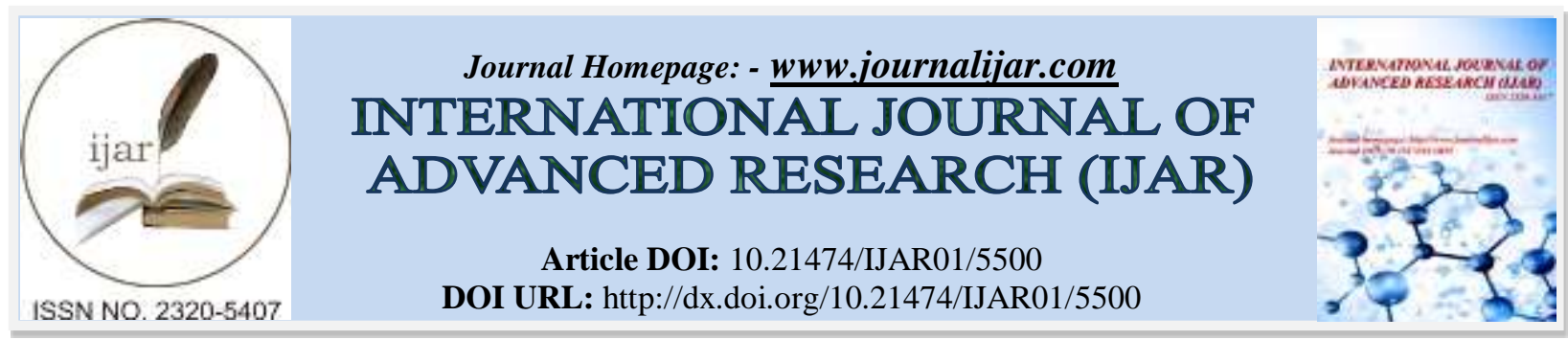

RESEARCH ARTICLE

\title{
POLLEN MORPHOLOGICAL STUDIES IN TWENTY ACCESSIONS OF JASMINUM SAMBAC (L.)AIT. FROM KERALA.
}

\author{
"Smitha S Nair ${ }^{1}$, Devipriya $V^{2}$ and Regy Yohannan ${ }^{1}$. \\ 1. Post Graduate \& Research Department of Botany, Sree Narayana College, Kollam, Kerala. \\ 2. Department of Botany, Sree Narayana College, Chempazhanthy, Thiruvananthapuram, Kerala.
}

\section{Manuscript Info}

Manuscript History

Received: 22 July 2017

Final Accepted: 24 August 2017

Published: September 2017

Key words:-

Jasminum sambac, accessions, Kerala, pollen morphology, exine architecture.

\begin{abstract}
The pollen morphology of 20 accessions of Jasminum sambac L.(Ait) collected from different parts of Kerala State were studied. The major palynological features relating to the pollen shape, aperture and exine ornamentation are conserved within the species. The pollen grains were in general spheroidal, medium-sized and 3(4) - zonocolporate with reticulate exine ornamentation. SEM analysis revealed microvariations relating to the exine components such as muri and lumina. Although these variations were not adequate enough to classify the taxa into palynological groups, certain character associations were observed such as the link between homobrochate condition and oval or ellipsoidal lumina. Four accessions with very short lumina and almost porous exine had spiny projections or pyramidal tapering from their upper mural ends. The phylogenetic significance of such microstructural variations in the pollen exine remain to be evaluated based on SEM studies of the exine architecture including more taxa belonging to the group.
\end{abstract}

Copy Right, IJAR, 2017,. All rights reserved.

\section{Introduction:-}

Pollen morphological features relating to the aperture, exine ornamentation, exine strata, pollen size and pollen shape have been used as 'palynological markers' in the study of systematic relationships and phylogeny of angiosperms at all taxonomic levels. The pollen grains of the Oleaceae in general are tricolpate with a reticulate exine, exhibiting consistency in the expression of major palynological traits. Erdtman (1971) and Nilsson (1988) opined that pollen traits of the taxa are of little taxonomic significance in the family. Earlier studies on the pollen of the genus Jasminum include those by Nair (1965), Raman et al. (1972), Jin-Tan (1982), Zhongxin et al (1988) etc.

Jasminum sambac (L.) Ait., commonly referred to as Arabian Jasmine, is native to southern Asia (Green and Miller, 2009). The species exhibits a wide range of morphological variation relating to its vegetative and floral features, and has a number of cultivars known by differing vernacular names such as kuttimulla, kudamulla, arimulla, iruvachimulla, moonnadukkumulla, adukkumulla etc., grown all over the State of Kerala as garden ornamentals. Earlier studies on the pollen morphology of the species have focused largely on light microscopic observations. But the advent of high end tools such as the Scanning Electron Microscope has enabled in-depth analysis of the intricate patterns of exine ornamentation, opening up new vistas of exploration. Nair and Kapoor (1974) demonstrated that statistical evaluation of pollen variations can be used as an effective tool in the categorization of varieties, and also in the understanding of the hybridity status of the cultivars within a taxon. Hence the present study is undertaken to 
make a detailed comparative intraspecific analysis of the pollen from twenty accessions of Jasminum sambac from Kerala using LM and SEM studies, and to evaluate the significance of palynology in the systematics of the speciescomplex.

\section{Materials and Methods:-}

Twenty accessions of Jasminum sambac (L.) Ait. were collected from various locations in the State of Kerala. Polliniferous materials from the collected specimen were fixed in glacial acetic acid. The details regarding the 20 taxa included in the present study are furnished in Table 1.

Table 1:- List of Jasminum sambac (L.)Ait. accessions collected from different parts of Kerala with locality

\begin{tabular}{|c|c|c|c|c|c|c|}
\hline Sl.No & $\begin{array}{l}\text { Accession } \\
\text { Name }\end{array}$ & $\begin{array}{l}\text { No. of } \\
\text { petal } \\
\text { tiers }\end{array}$ & Locality & District & $\mathbf{N}$ & $\mathbf{E}$ \\
\hline 1 & AC-1 & 1 & Chirayinkeezhu & Thiruvananthapuram & $8^{\circ} 39^{\prime} 54^{\prime \prime}$ & $76^{\circ} 47^{\prime} 54^{\prime \prime}$ \\
\hline 2 & AC-2 & $2-3$ & Anathalavattom & Thiruvananthapuram & $8^{\circ} 39^{\prime} 56^{\prime \prime}$ & $76^{\circ} 46^{\prime} 19^{\prime \prime}$ \\
\hline 3 & AC-3 & 1 & Koonthalloor & Thiruvananthapuram & $8^{\circ} 39^{\prime} 54^{\prime \prime}$ & $76^{\circ} 47^{\prime} 53^{\prime \prime}$ \\
\hline 4 & AC-4 & 2 & Neyyattinkara & Thiruvananthapuram & $8^{\circ} 23^{\prime} 20^{\prime \prime}$ & $77^{\circ} 5^{\prime} 60^{\prime \prime}$ \\
\hline 5 & AC-5 & $2-3$ & Mamom, Attingal & Thiruvananthapuram & $8^{\circ} 41^{\prime} 11^{\prime \prime}$ & $76^{\circ} 49^{\prime} 21^{\prime \prime}$ \\
\hline 6 & AC-6 & several & Moonnumukku, Attingal & Thiruvananthapuram & $8^{\circ} 41^{\prime} 12^{\prime \prime}$ & $76^{\circ} 49^{\prime} 21^{\prime \prime}$ \\
\hline 7 & AC-7 & several & Palace Road, Attingal & Thiruvananthapuram & $8^{\circ} 41^{\prime} 38^{\prime \prime}$ & $76^{\circ} 48^{\prime} 44^{\prime \prime}$ \\
\hline 8 & AC-8 & $2-5$ & Mamom, Attingal & Thiruvananthapuram & $8^{\circ} 41^{\prime} 12^{\prime \prime}$ & $76^{\circ} 49^{\prime} 21^{\prime \prime}$ \\
\hline 9 & AC-9 & 1 & Moonnumukku, Attingal & Thiruvananthapuram & $8^{\circ} 41^{\prime} 12^{\prime \prime}$ & $76^{\circ} 49^{\prime} 21^{\prime \prime}$ \\
\hline 10 & AC-10 & $2-5$ & Kariavattom & Thiruvananthapuram & $8^{\circ} 33^{\prime} 54^{\prime \prime}$ & $76^{\circ} 53^{\prime} 2^{\prime \prime}$ \\
\hline 11 & $\mathrm{AC}-11$ & $2-3$ & Kariavattom & Thiruvananthapuram & $8^{\circ} 33^{\prime} 54^{\prime \prime}$ & $76^{\circ} 53^{\prime} 3^{\prime \prime}$ \\
\hline 12 & AC-12 & $2-5$ & Kacherinada, Attingal & Thiruvananthapuram & $8^{\circ} 41^{\prime} 56^{\prime \prime}$ & $76^{\circ} 48^{\prime} 59^{\prime \prime}$ \\
\hline 13 & $\mathrm{AC}-13$ & 1 & Kulanada, Pandalam & Pathanamthitta & $9^{\circ} 13^{\prime} 22^{\prime \prime}$ & $76^{\circ} 40^{\prime} 38^{\prime \prime}$ \\
\hline 14 & $\mathrm{AC}-14$ & $2-3$ & Chalakkudy & Thrissur & $10^{\circ} 18^{\prime} 5^{\prime \prime}$ & $76^{\circ} 9^{\prime} 19^{\prime \prime}$ \\
\hline 15 & $\mathrm{AC}-15$ & $2-3$ & Pallikkara & Ernakulam & $10^{\circ} 1^{\prime} 8^{\prime \prime}$ & $76^{\circ} 22^{\prime} 59^{\prime \prime}$ \\
\hline 16 & $\mathrm{AC}-16$ & 2 & Azheekkal & Alappuzha & $9^{\circ} 29^{\prime} 54^{\prime \prime}$ & $76^{\circ} 20^{\prime} 56^{\prime \prime}$ \\
\hline 17 & $\mathrm{AC}-17$ & $2-3$ & Pattambi & Palakkad & $10^{\circ} 47^{\prime} 2^{\prime \prime}$ & $76^{\circ} 9^{\prime} 40^{\prime \prime}$ \\
\hline 18 & AC-18 & 1 & ThazheChowva & Kannur & $11^{\circ} 52^{\prime} 33^{\prime \prime}$ & $75^{\circ} 21^{\prime} 46^{\prime \prime}$ \\
\hline 19 & AC-19 & $2-3$ & Thalankara & Kasargod & $12^{\circ} 29^{\prime} 29^{\prime \prime}$ & $74^{\circ} 59^{\prime} 17^{\prime \prime}$ \\
\hline 20 & AC-20 & 1 & Kozhikode Beach & Kozhikode & $11^{\circ} 14^{\prime} 46^{\prime \prime}$ & $75^{\circ} 46^{\prime} 49^{\prime \prime}$ \\
\hline
\end{tabular}

\section{Palynological analysis:-}

Fresh anthers from mature unopened flower buds were fixed in glacial acetic acid. Pollen preparations were made by the acetolysis method standardized by Erdtman (1952) and modified by Nair (1970). The pollen shape and size classes were ascertained following the classifications suggested by Erdtman(1966) and Walker \& Doyle (1975) respectively. The terminologies suggested by Punt et al. (1994) were adopted for describing the aperture types and exine ornamentation patterns. Measurements relating to the following characters were taken using an ocular micrometer. In each case, the mean values of the measurements were taken from a random sample of 30 pollen grains.

\section{Quantitative characters:-}

1. Polar diameter of pollen grain $(\mu \mathrm{m})-\mathrm{P}$

2. Equatorial diameter of pollen grain $(\mu \mathrm{m})-\mathrm{E}$

3. $\mathrm{P} / \mathrm{E}$ ratio

4. Thickness of exine $(\mu \mathrm{m})$

5. Number of apertures

\section{Qualitative characters:-

$\begin{array}{ll}1 & \text { Pollen shape } \\ 2 & \text { Pollen type } \\ 3 & \text { Pollen size class }\end{array}$

$\begin{array}{ll}8 & \text { Muri height } \\ 9 & \text { Lumina depth } \\ 10 & \text { Lumina floor nature }\end{array}$


4

5

6

7

\author{
Exine ornamentation \\ Muri shape \\ Muri wall nature \\ Muri width
}

11

12

13

\author{
Lumina shape \\ Wax plugging in lumina \\ Aperture shape
}

LM photomicrographs of the pollen preparations were taken using an Olympus CH - 20 Research Microscope with Digital camera attachment facility. The slides of pollen preparation are deposited in the Department of Botany, Sree Narayana College, Kollam. SEM pictures were taken at the NIIST, Pappanamcode, Trivandrum using a JEOL JSM - 5600LV scanning electron microscope.

\section{Results and Discussion:-}

Details of pollen morphological characters observed from 20 accessions of Jasminum sambac L.(Ait) collected from different parts of Kerala State are represented in Tables 2a-b and 3a-b. Among the twenty accessions studied, only fourteen yielded adequate pollen material for the study (Figs. 1-38 in Plates I and II). Pollen from the remaining taxa appeared to be disfigured in the palynological preparations and hence could not be used for the comparative analysis.

The pollen are in general medium-sized, 3(4) - zonocolporate and spheroidal with the polar and equatorial diameters ranging from $49.8 \pm 8.63 \mu \mathrm{m}$ and $46.8 \pm 10.20 \mu \mathrm{m}$ to $35.1 \pm 9.80 \mu \mathrm{m}$ and $33.60 \pm 9.14 \mu \mathrm{m}$ respectively (Tables $2 \mathrm{a}-\mathrm{b})$. The largest pollen grains were observed in AC 10 and the smallest in AC 15 (Figs. 17, 27). Exine $3.3 \pm 0.22 \mu \mathrm{m}$ to $4.98 \mu \mathrm{m} \pm 0.51 \mu \mathrm{m}$ thick, thinner towards the colpi margins and reticulate. The aperture number was 3 in almost all accessions except in AC 5 which showed 4 colpi in some of its pollen grains (Fig. 10).

Table 2a:- Quantitative pollen morphological characters in 14 accessions of Jasminum sambac L.(Ait) from Kerala

\begin{tabular}{|l|l|l|l|l|l|l|l|}
\hline Characters & AC 2 & AC3 & AC4 & AC5 & AC6 & AC8 & AC10 \\
\hline Polar diameter $-\mathrm{P}(\mu \mathrm{m})$ & $43.5 \pm 8.86$ & $42 \pm 7.35$ & $42.3 \pm 6.7$ & $39.3 \pm 5.38$ & $42.9 \pm 4.48$ & $45.6 \pm 6.45$ & $49.8 \pm 8.63$ \\
\hline Equatorial diam.- E $(\mu \mathrm{m})$ & $41.4 \pm 8.46$ & $40.5 \pm 7.78$ & $41.1 \pm 6.33$ & $36.6 \pm 5.62$ & $41.1 \pm 4.01$ & $42 \pm 7.07$ & $46.8 \pm 9.08$ \\
\hline P/E & $1.05 \pm 0.07$ & $1.04 \pm 0.11$ & $1.03 \pm 0.07$ & $1.08 \pm 0.09$ & $1.05 \pm 0.06$ & $1.09 \pm 0.05$ & $1.07 \pm 0.06$ \\
\hline Exine thickness $(\mu \mathrm{m})$ & $3.33 \pm 0.22$ & $3.9 \pm 0.76$ & $3.45 \pm 0.38$ & $3.3 \pm 0.32$ & $3.18 \pm 0.29$ & $4.11 \pm 0.8$ & $4.98 \pm 0.51$ \\
\hline Aperture number & 3 & 3 & 3 & $3-4$ & 3 & 3 & 3 \\
\hline
\end{tabular}

Table 2b:- Quantitative pollen morphological characters in 14 accessions of Jasminum sambac L.(Ait) from Kerala

\begin{tabular}{|l|l|l|l|l|l|l|l|}
\hline Characters & AC12 & AC 14 & AC 15 & AC 16 & AC17 & AC 19 & AC 20 \\
\hline Polar diameter $-\mathrm{P}(\mu \mathrm{m})$ & $47.1 \pm 8.61$ & $45.9 \pm 5.84$ & $35.1 \pm 9.8$ & $42.6 \pm 8.34$ & $40.5 \pm 5.34$ & $48.6 \pm 11.7$ & $44.1 \pm 7.49$ \\
\hline Equatorial diam.- E $(\mu \mathrm{m})$ & $44.7 \pm 10.2$ & $45 \pm 6.48$ & $33.6 \pm 9.14$ & $41.4 \pm 8.1$ & $39.9 \pm 6.49$ & $46.8 \pm 10.2$ & $40.2 \pm 5.87$ \\
\hline P/E & $1.07 \pm 0.1$ & $1.03 \pm 0.11$ & $1.06 \pm 0.1$ & $1.03 \pm 0.1$ & $1.02 \pm 0.08$ & $1.04 \pm 0.11$ & $1.1 \pm 0.1$ \\
\hline Exine thickness $(\mu \mathrm{m})$ & $3.87 \pm 0.5$ & $3.48 \pm 0.29$ & $3.42 \pm 0.32$ & $4.14 \pm 0.9$ & $3.3 \pm 0.32$ & $4.68 \pm 0.78$ & $4.14 \pm 0.75$ \\
\hline Aperture number & 3 & 3 & 3 & 3 & 3 & 3 & 3 \\
\hline
\end{tabular}

The major qualitative palynological features were also conserved within the species with the members having mostly spheroidal, 3-zonocolporate, medium-sized pollen with reticulate exine ornamentation (Tables 3a-b). Only one accession (AC 5) showed occasionally 4-zonocolporate pollen in addition to the more frequent 3-zonocolporate ones. Although the lumina were irregular in size due to varying mural traits, the pollen could be broadly categorized into homobrochate and heterobrochate types (Figs. 1, 20). The former was observed in only three taxa (AC 2, 3 and 10). Muri were very tall, narrow or broad, with upper end flat and smooth in most accessions, except in AC 5 where it was pyramidal (Fig. 11). Small granular warts were observed on the mural surface in some taxa - AC 2, 3, 4, and 17. The accession AC 12 showed slight granulation on its mural surfaces, with the granules not assuming the form of warts. The accessions AC 8, 14 and 15 showed spiny projections from the mural wall (Plate III).

The lumina were very deep with the luminal floor not clearly visible due to the tallness of the mural walls in almost all cases, except in AC 20 where few warts and perforations were noted in the lumina. Even in this case, the mural walls were tall. In homobrochate forms the lumina appeared oval or ellipsoidal, while the heterobrochate pollen had narrow and irregularly elongated lumina. Interestingly, the four taxa with pyramidal projection or spiny outgrowths from the mural wall had very short and irregularly narrow lumina giving a porous appearance to the pollen exine. In all other taxa, the lumina were more prominent giving a reticulate appearance. The lumina appeared to be plugged with waxy material in three accessions - AC 4, 5 and 15. 
Table 3a:- Qualitative pollen morphological characters in in 14 accessions of Jasminum sambac (L.) Ait. from

Kerala

\begin{tabular}{|c|c|c|c|c|c|c|c|}
\hline Characters & AC 2 & AC3 & AC4 & AC5 & AC6 & AC8 & AC10 \\
\hline Pollen shape & Spheroidal & Spheroidal & Spheroidal & Spheroidal & Spheroidal & Spheroidal & Spheroidal \\
\hline Pollen type & $\begin{array}{l}3- \\
\text { zonocolporate }\end{array}$ & $\begin{array}{l}3- \\
\text { zonocolporate }\end{array}$ & 3-zonocolporate & $\begin{array}{l}\text { 3-4 } \\
\text { zonocolporat } \\
\mathrm{e}\end{array}$ & $\begin{array}{l}\text { 3- } \\
\text { zonocolporat } \\
\text { e }\end{array}$ & $\begin{array}{l}3- \\
\text { zonocolporate }\end{array}$ & $\begin{array}{l}3- \\
\text { zonocolporate }\end{array}$ \\
\hline $\begin{array}{l}\text { Pollen size- } \\
\text { class }\end{array}$ & Medium & Medium & Medium & Medium & Medium & Medium & Medium \\
\hline $\begin{array}{l}\text { Exine } \\
\text { ornamentation }\end{array}$ & Reticulate & Reticulate & Reticulate & Reticulate & Reticulate & Reticulate & Reticulate \\
\hline Muri shape & $\begin{array}{l}\text { Homobrochat } \\
\text { e }\end{array}$ & Homobrochate & Heterobrochate & $\begin{array}{l}\text { Heterobrocha } \\
\text { te }\end{array}$ & $\begin{array}{l}\text { Heterobroch } \\
\text { ate }\end{array}$ & $\begin{array}{l}\text { Heterobrochat } \\
\text { e }\end{array}$ & Homobrochate \\
\hline $\begin{array}{l}\text { Muri wall } \\
\text { nature }\end{array}$ & $\begin{array}{l}\text { Flat, smooth, } \\
\text { outer surface } \\
\text { often with } \\
\text { small } \\
\text { granular } \\
\text { warts } \\
\end{array}$ & $\begin{array}{l}\text { Flat, smooth, } \\
\text { outer surface } \\
\text { often with } \\
\text { small granular } \\
\text { warts }\end{array}$ & $\begin{array}{l}\text { Flat, smooth, } \\
\text { outer surface } \\
\text { often with small } \\
\text { granular warts }\end{array}$ & $\begin{array}{l}\text { Pyramidal, } \\
\text { smooth }\end{array}$ & Flat, smooth & $\begin{array}{l}\text { Flat, smooth } \\
\text { with spiny } \\
\text { projections } \\
\text { from corners }\end{array}$ & Flat, smooth \\
\hline Muri width & Less broad & Less broad & Less broad & Narrow & Broad & Narrow & Less broad \\
\hline Muri height & Very tall & Very tall & Very tall & Very tall & Very tall & Very tall & Very tall \\
\hline Lumina depth & Very deep & Very deep & Very deep & Very deep & Very deep & Very deep & Very deep \\
\hline $\begin{array}{l}\text { Lumina floor } \\
\text { nature }\end{array}$ & $\begin{array}{l}\text { Smooth, not } \\
\text { clearly visible } \\
\text { due to the } \\
\text { height of } \\
\text { muri }\end{array}$ & $\begin{array}{l}\text { Smooth, not } \\
\text { clearly visible } \\
\text { due to the } \\
\text { height of muri }\end{array}$ & $\begin{array}{l}\text { Granular, not } \\
\text { clearly visible } \\
\text { due to the } \\
\text { height of muri }\end{array}$ & $\begin{array}{l}\text { Smooth, not } \\
\text { clearly } \\
\text { visible due to } \\
\text { the height of } \\
\text { muri }\end{array}$ & $\begin{array}{l}\text { Smooth, not } \\
\text { clearly } \\
\text { visible due } \\
\text { to the height } \\
\text { of muri }\end{array}$ & $\begin{array}{l}\text { Smooth, not } \\
\text { clearly visible } \\
\text { due to the } \\
\text { height of muri }\end{array}$ & $\begin{array}{l}\text { Smooth, not } \\
\text { clearly visible } \\
\text { due to the } \\
\text { height of muri }\end{array}$ \\
\hline Lumina shape & $\begin{array}{l}\text { Oval or } \\
\text { ellipsoidal }\end{array}$ & $\begin{array}{l}\text { Oval or } \\
\text { ellipsoidal }\end{array}$ & $\begin{array}{l}\text { Narrow } \\
\text { irregularly } \\
\text { elongated }\end{array}$ & $\begin{array}{l}\text { Very short } \\
\text { and } \\
\text { irregularly } \\
\text { narrow, } \\
\text { appearing } \\
\text { porous }\end{array}$ & $\begin{array}{l}\text { Irregularly } \\
\text { elongated }\end{array}$ & $\begin{array}{l}\text { Short, } \\
\text { irregular, } \\
\text { appearing } \\
\text { slightly } \\
\text { porous }\end{array}$ & $\begin{array}{l}\text { Oval or } \\
\text { ellipsoidal }\end{array}$ \\
\hline $\begin{array}{l}\text { Wax plugging } \\
\text { in lumina }\end{array}$ & Absent & Absent & Present & Present & Absent & Absent & Absent \\
\hline $\begin{array}{l}\text { Aperture } \\
\text { shape }\end{array}$ & Colporate & Colporate & Colporate & Colporate & Colporate & Colporate & Colporate \\
\hline
\end{tabular}

Table 3b:- Qualitative pollen morphological characters in in 14 accessions of Jasminum sambac (L.) Ait. from

Kerala

\begin{tabular}{|c|c|c|c|c|c|c|c|}
\hline Characters & AC12 & AC 14 & AC 15 & AC 16 & AC17 & AC 19 & AC 20 \\
\hline Pollen shape & Spheroidal & Spheroidal & Spheroidal & Spheroidal & Spheroidal & Spheroidal & Spheroidal \\
\hline Pollen type & $\begin{array}{l}\text { 3- } \\
\text { zonocolporat } \\
\text { e }\end{array}$ & $\begin{array}{l}\text { - } \\
\text { zonocolporate }\end{array}$ & $\begin{array}{l}\text { 3- } \\
\text { zonocolporate }\end{array}$ & $\begin{array}{l}\text { 3- } \\
\text { zonocolporat } \\
\text { e }\end{array}$ & $\begin{array}{l}\text { 3- } \\
\text { zonocolporat } \\
\text { e }\end{array}$ & $\begin{array}{l}\text { 3- } \\
\text { zonocolporate }\end{array}$ & $\begin{array}{l}\text { 3- } \\
\text { zonocolporate }\end{array}$ \\
\hline $\begin{array}{l}\text { Pollen size- } \\
\text { class }\end{array}$ & Medium & Medium & Medium & Medium & Medium & Medium & Medium \\
\hline $\begin{array}{l}\text { Exine } \\
\text { ornamentation }\end{array}$ & Reticulate & Reticulate & Reticulate & Reticulate & Reticulate & Reticulate & Reticulate \\
\hline Muri shape & $\begin{array}{l}\text { Heterobroch } \\
\text { ate }\end{array}$ & Heterobrochate & Heterobrochate & $\begin{array}{l}\text { Heterobrocha } \\
\text { te }\end{array}$ & $\begin{array}{l}\text { Heterobroch } \\
\text { ate }\end{array}$ & $\begin{array}{l}\text { Heterobrochat } \\
\text { e }\end{array}$ & $\begin{array}{l}\text { Heterobrochat } \\
\text { e }\end{array}$ \\
\hline $\begin{array}{l}\text { Muri wall } \\
\text { nature }\end{array}$ & $\begin{array}{l}\text { Flat, smooth, } \\
\text { outer surface } \\
\text { slightly } \\
\text { granular }\end{array}$ & $\begin{array}{l}\text { Flat, smooth, } \\
\text { with } \\
\text { occasional } \\
\text { spiny } \\
\text { projections }\end{array}$ & $\begin{array}{l}\text { Flat, smooth, } \\
\text { with } \\
\text { occasional } \\
\text { spiny } \\
\text { projections }\end{array}$ & Flat, smooth & $\begin{array}{l}\text { Flat, smooth, } \\
\text { outer surface } \\
\text { with small } \\
\text { granular } \\
\text { warts }\end{array}$ & Flat, smooth & Flat, smooth \\
\hline Muri width & Broad & Narrow & Narrow & Less broad & Less broad & Broad & Broad \\
\hline Muri height & Very tall & Very tall & Very tall & Very tall & Very tall & Very tall & Very tall \\
\hline Lumina depth & Very deep & Very deep & Very deep & Very deep & Very deep & Very deep & Very deep \\
\hline $\begin{array}{l}\text { Lumina floor } \\
\text { nature }\end{array}$ & $\begin{array}{l}\text { Smooth, not } \\
\text { clearly } \\
\text { visible due to } \\
\text { the height of } \\
\text { muri }\end{array}$ & $\begin{array}{l}\text { Smooth, not } \\
\text { clearly visible } \\
\text { due to the } \\
\text { height of muri }\end{array}$ & $\begin{array}{l}\text { Smooth, not } \\
\text { clearly visible } \\
\text { due to the } \\
\text { height of muri }\end{array}$ & $\begin{array}{l}\text { Smooth, not } \\
\text { clearly } \\
\text { visible due to } \\
\text { the height of } \\
\text { muri }\end{array}$ & $\begin{array}{l}\text { Smooth, not } \\
\text { clearly } \\
\text { visible due } \\
\text { to the height } \\
\text { of muri }\end{array}$ & $\begin{array}{l}\text { Smooth, not } \\
\text { clearly visible } \\
\text { due to the } \\
\text { height of muri }\end{array}$ & $\begin{array}{l}\text { With few } \\
\text { warts and } \\
\text { perforations }\end{array}$ \\
\hline Lumina shape & $\begin{array}{l}\text { Narrow } \\
\text { irregularly } \\
\text { elongated }\end{array}$ & $\begin{array}{l}\text { Short, } \\
\text { irregular, } \\
\text { appearing }\end{array}$ & $\begin{array}{l}\text { Short, } \\
\text { irregular, } \\
\text { appearing }\end{array}$ & $\begin{array}{l}\text { Narrow } \\
\text { irregularly } \\
\text { elongated }\end{array}$ & $\begin{array}{l}\text { Narrow } \\
\text { irregularly } \\
\text { elongated }\end{array}$ & $\begin{array}{l}\text { Narrow } \\
\text { irregularly } \\
\text { elongated }\end{array}$ & $\begin{array}{l}\text { Narrow } \\
\text { irregularly } \\
\text { elongated }\end{array}$ \\
\hline
\end{tabular}




\begin{tabular}{|l|l|l|l|l|l|l|l|}
\hline & & slightly porous & slightly porous & & & \\
\hline $\begin{array}{l}\text { Wax plugging } \\
\text { in lumina }\end{array}$ & Absent & Absent & Present & Absent & Absent & Absent \\
\hline $\begin{array}{l}\text { Aperture } \\
\text { shape }\end{array}$ & Colporate & Colporate & Colporate & Colporate & Colporate & Colporate & Colporate \\
\hline
\end{tabular}

\section{Conclusions:-}

The pollen observed from 20 accessions of Jasminum sambac L.(Ait) collected from different parts of Kerala State were in general spheroidal, medium-sized and 3(4) - zonocolporate with reticulate exine ornamentation. These characters are largely consistent with the pollen features reported for the genus and its family, the Oleaceae. Thus the major palynological features are conserved within the species and its higher level groups. Erdtman (1971) and Nilsson (1988) had earlier opined that pollen characters are not good taxonomic markers for the family Oleaceae. The results from the present study corroborate their findings. However, the fine exine architecture revealed through SEM analysis reflected the microvariations with regard to exine components such as the muri and lumina. These microvariations were not adequate enough to group the taxa studied into palynological classes. Certain character associations were also observed such as the correlation between homobrochate condition and oval or ellipsoidal lumina. In addition, spiny projections or pyramidal tapering from the upper mural ends were noted in the four accessions with very short lumina and almost porous exines. The phylogenetic significance of such microstructural variations in the pollen exine remain to be evaluated based on SEM studies on more taxa belonging to the group. 

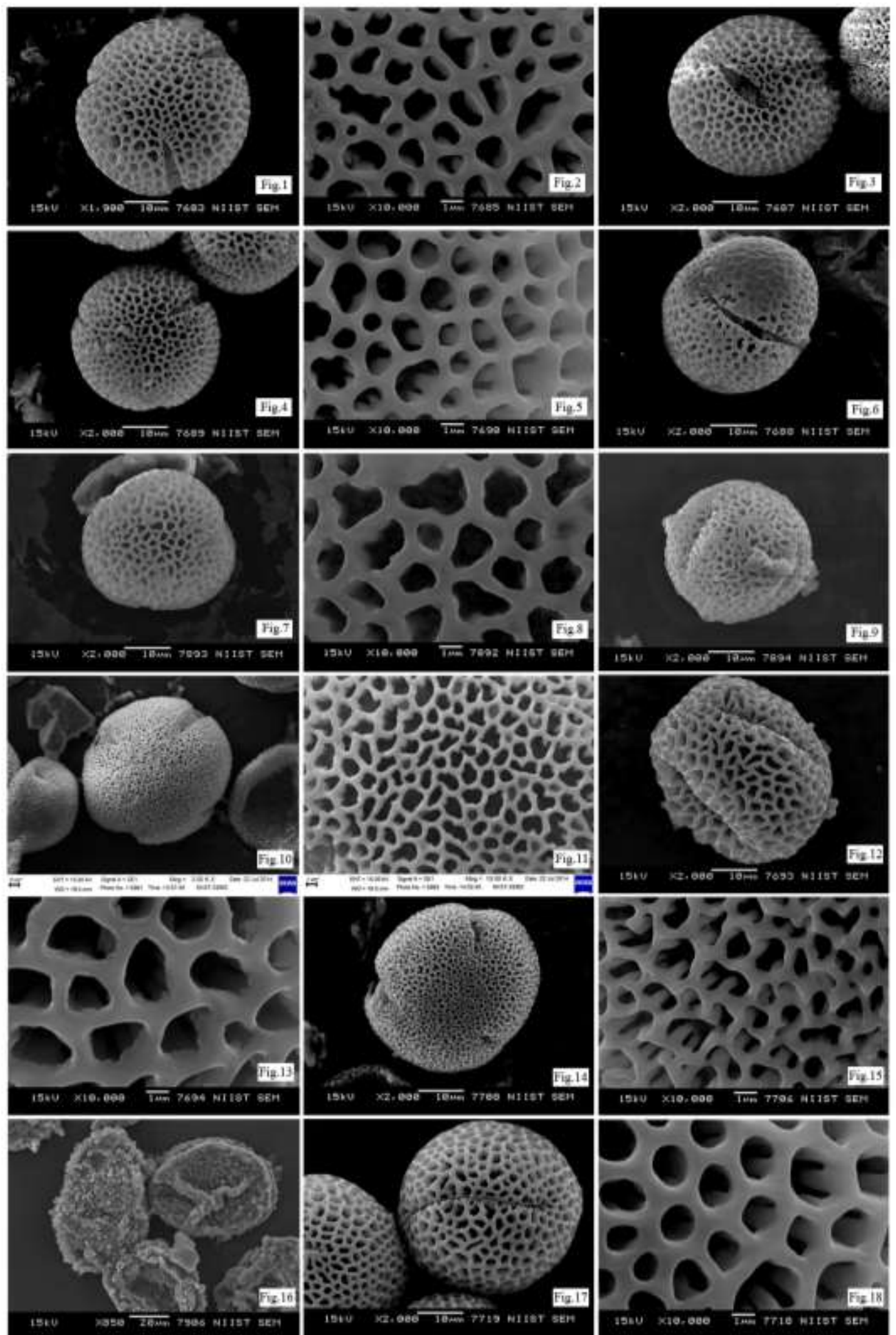

Plate I:- Figs.1-3:AC 2 pollen- 1,900x ,10,000x,2,000x; Figs.4-6:AC 3 pollen-2000x, 10,000x,2000x; Figs.7-9:AC 4 pollen-2000x,10,000x,2,000x; Figs.10-11:AC 5 pollen- 3000x, 10,000x; Figs.12-13:AC 6pollen- 2,000x, 10,000x; Figs.14-15:AC 8 pollen-2,000x,10,000x; Figs.16:AC 9 pollen-850x; Figs.1718:AC10pollen-2,000x,10,000x. 


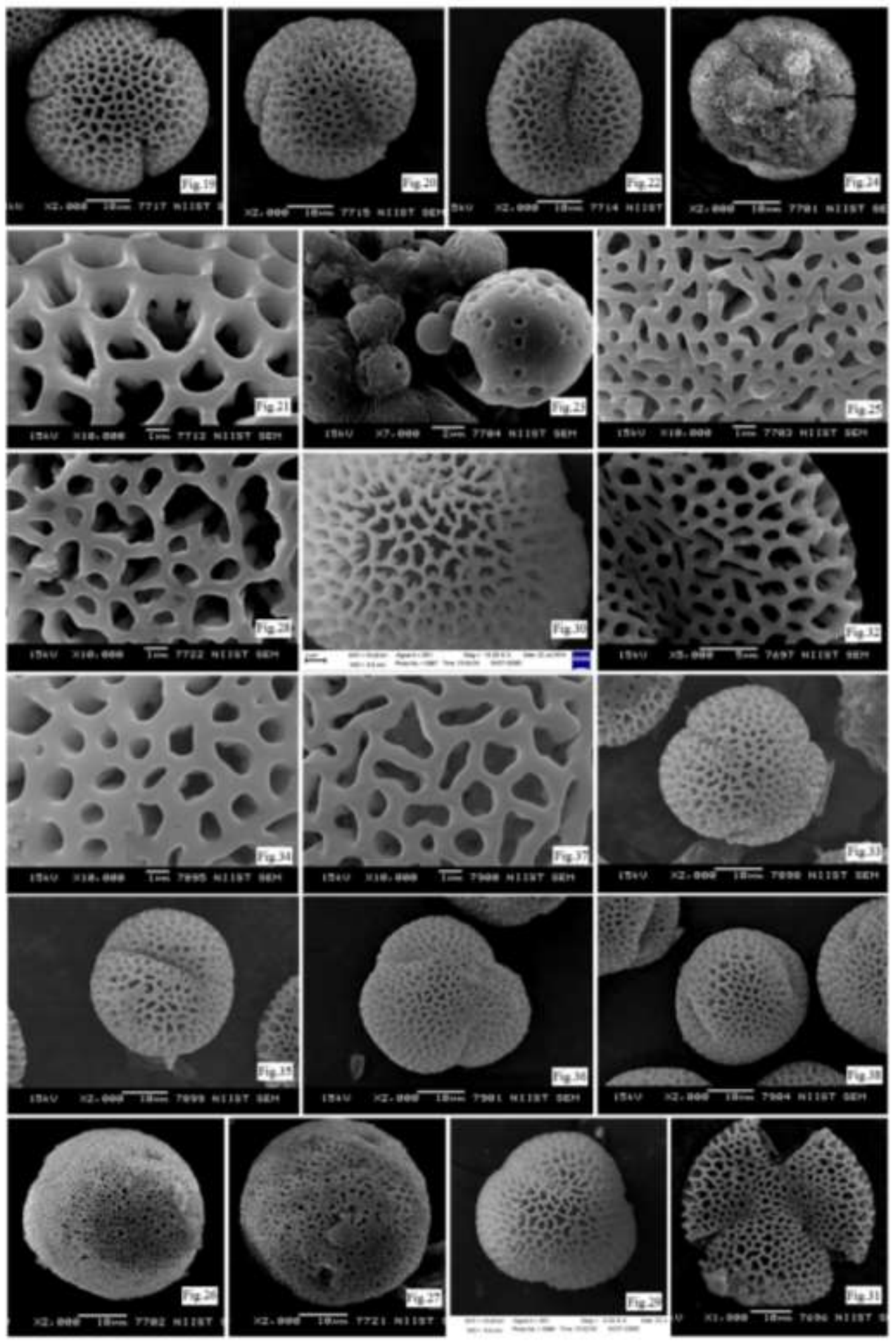

Plate II:- Fig.19:AC10 pollen-,2,000x; Figs.20-22:AC12pollen-2,000x,10,000x,2,000x; Figs.23:AC13 pollen-7,000x; Figs 24-26:AC 14 pollen-2,000x,10,000x,2,000x; Figs.27-28:AC 15 pollen-2,000x,10,000x; Figs.29-30: AC16 pollen5000x,10,000x; Figs.31-32:AC17 pollen -1800x,5000x; Figs.33-35:AC19 pollen-2,000x,10,000x,2,000x; Figs.3638:AC 20 pollen-2,000x,10,000x,2,000x. 


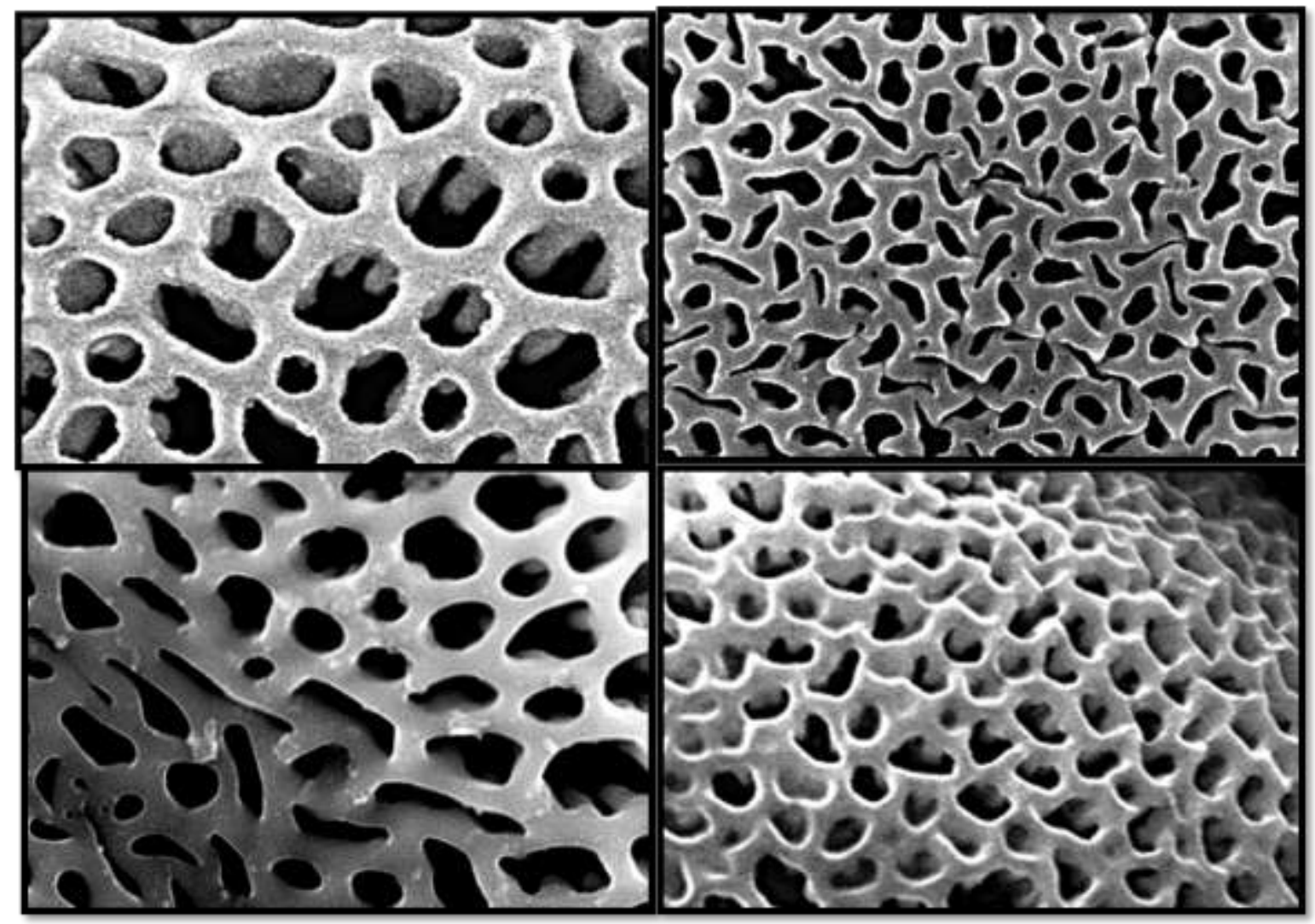

Plate III:- Muri walls showing small granular warts, spiny projections and pyramidal tapering in accessions of Jasminum sambac

\section{Acknowledgements:-}

The authors are thankful to the University of Kerala for financial support and the Principals, Sree Narayana Colleges, Kollam and Chempazhanthy for facilities provided.

\section{References:-}

1. Erdtman G. 1952. Pollen Morphology and Plant Taxonomy of Angiosperms. Almquist and Wiksell, Stockholm.

2. Erdtman G. 1966. Pollen Morphology and Plant Taxonomy of Angiosperms. Corrected reprint of the edition of 1952 with a new addendum. Hafner Pub. No:NV.

3. Erdtman G. 1971. Pollen Morphology and Plant Taxonomy. Hafner Pub. New York.

4. Green PS \& Miller D. 2009. The genus Jasminum in cultivation. Kew Pub. Royal Botanic Gardens, Kew.

5. Jin-Tan Z. 1982. Study of pollen morphology of the Chinese family Oleaceae. Acta Botanica Sinica. 24(6) : 499-505.

6. Nair PKK. 1970. Pollen Morphology of Angiosperms. III. Historical and Phylogenetic Study. Vikas Pub. House, Delhi.

7. Nair PKK. 1965. Pollen grains of Western Himalayan Plants. Asia Pub. House, Bombay.

8. Nair, P.K.K. \& Kapoor, S.K. 1974. Pollen morphology of Indian vegetable crops. Glimpses in Plant Res. 2 : 106201.

9. Nilsson, S. 1988. A survey of the pollen morphology of Olea with particular reference to O. europea sensu lat. Kew Bull. 43 : 309-315.

10. Punt W, Blackmore S, Nilsson S \& Le Thomas A. 1994. Glossary of Pollen and Spore Terminology. LPP Contributions Series No.1. LPP Foundation, Uty. Of Utrecht, The Netherlands.

11. Raman KR, Khan WMA \& Shanmugan A. 1972. Palynological aspects of some species and varieties of Jasminum. J. Palynol., no. 6. 73-77.

12. Walker JW \& Doyle JA. 1975. The basis of angiosperm phylogeny: Palynology. Ann. Miss. Bot. Gard. 62:664-723.

13. Zhongxin W, Zhekun Z \& Peiyu B. 1988. Studies on the pollen morphology of the genus Jasminum. Acta Botanica Yunannica, 10(3) : 1-3. 